\title{
LOGIK
}

\section{Versuch einer Theorie der Wahrheit}

\author{
von \\ ÁKOS VON PAULER \\ o. ö. Professor der Philosophie an der Universität \\ Budapest
}

Aus dem Ungarischen übersetzt

von

Dr. Joseph Somogyi

1929

WALTER DE GRUYTER \& CO.

vormals G. J. Göschen'sche Verlagshandlung / J. Guttentag, Verlagsbuchhandlang / Georg Reimer/Karl J.Trübner / Veit \& Comp. BERLIN UND LEIPZIG 
Druck von Gerhard Stalling, Oldenburg i. O. 